\title{
Renal Pelvis and Ureter Cancer pTa TNM
} Finding v8

National Cancer Institute

\section{Source}

National Cancer Institute. Renal Pelvis and Ureter Cancer pTa TNM Finding v8. NCI

Thesaurus. Code C140342.

Renal pelvis and ureter cancer with a finding of papillary noninvasive carcinoma. (from AJCC 8th Ed.) 